\title{
A Review of Drama-based and Music-based Pedagogy in Early Childhood Language Learning and Development
}

\author{
Ziyu $\mathrm{Wu}^{1, *}$ \\ ${ }^{I}$ School of music, the University of Queensland, Brisbane, Queensland, Australia \\ *Corresponding author email: z.wul@uqconnect.edu.au
}

\begin{abstract}
Past research on the issues and methods of drama-based and music-based activities on early childhood language learning has been investigated. However, related research on Chinese primary students remains unclear. The present study aims to analyse various teaching activities worldwide, including teaching aims, methods and results. Moreover, it will compare relative issues between a Chinese context and worldwide. Nine drama-based activities will be discussed, including five western students and four Chinese studies; Ten music-based activities will be explained, including eight western studies and two Chinese studies. The results show that drama-based activities in early childhood language learning were developed systematically with corresponding teaching methods such as "roleplaying", "script-writing", and "text interpretation". Music-based activities in early childhood language learning were analysed through teaching models among music teaching and language therapy, sensory simulations, materials and pedagogy. More studies need to look at music-based activities in early childhood language learning in both curriculum and teaching training in a Chinese context.
\end{abstract}

Keywords: Music activities, Drama activities, Early childhood, Language learning and development.

\section{INTRODUCTION}

It has been widely accepted that drama can work as a creative learning tool to help enhance early childhood language learning and development. Studies illustrated that music based activities were applicable globally as a language learning tool in early childhood. However, based on the current literature in a Chinese context, with the key words: 'drama, music, and language learning', only several peer-reviewed articles that discussed drama-based language learning pedagogy and musicbased language pedagogy was found.

This proposal aims to find music-based and dramabased teaching activities that help improve early childhood language learning by comparing and analyzing various teaching activities worldwide. Several music-based and drama-based activities in early childhood language learning under different cultural backgrounds will be discussed, including teaching aims, methods and results.

\section{DRAMA-BASED PEDAGOGY IN LANGUAGE LEARNING}

The current literature regarding music pedagogy in language learning aims to enhance students' capacity to learn and use a language, such as understanding a language context [1] and improvisation skills while communicating [2]. In addition, studies have addressed learning motivation as one of the key outcomes regarding drama-based pedagogy in language learning.

\subsection{Drama-based activities in educational understanding and language writing}

Studies in England have already investigated dramabased teaching training programs to support teachers' ability of language teaching.

Aimed to understand the transformative implementation between drama, digital film, and computer games to enhance teachers' ability to understand and write literary text [1]. They recruited a group of postgraduate English and Drama student 
teachers and conducted a two-day workshop from 2015 to 2016. Based on [3] and [4], which highlight reading as a transformation of acting or performance and writing as a transformation of role-playing, the workshop guided teachers to design their productions of drama, film making, and video games. The study suggests that the pedagogy that links drama, film-making, and video games engage participants in new ideas when understanding the literary text.

\subsection{Drama-based activities in early childhood communication skills [5]}

Introduced three drama pedagogy which implemented in a south-east Asian context, including 1) text interpretation and performance, 2) improvisations, and 3) role plays and process dramas. That three pedagogy were designed to enhance students' motivations and confidence to use the second language they learned. All activities involve verbal and nonverbal interactions between students based on an imaginary world context. Students' verbal communication skills were enhanced through text interpretation and performance approaches such as characterization, vocal and physical exercise. Using improvisations, students spontaneously interact through imaginative real-life themes of acting; process drama activities enhance students' ability to interpret a text and improvisation skills while communicating with people

\subsection{Drama-based activities in early childhood language learning motivation}

One of the unique functions of drama-based activities is that facilitating students' language learning motivation.

Scriptwriting is an activity in which students write their ideas in English to transform into physical acting [6]. mentions that scriptwriting motivates students to understand the English learning context in which they will engage [7].

Digital storytelling consists of a series of still images combined with a narrated soundtrack to tell a story, constructed from students' own experience and understanding of the world [8]. The goal of digital storytelling activities is to motivate students to explore their language expression [8].

Role-play is any speaking and listening activity when students either put themselves into somebody else's shoes or when they stay in their own shoes but put themselves into an imaginary situation. As [9] mentioned, role-play strategies that enhance students' motivation on English speaking, listening, and understanding will also be used as drama-based activities

\section{DRAMA-BASED PEDAGOGY IN A CHINESE CONTEXT}

There are some similarities regarding learning outcomes between Chinese educational drama-based activities and global drama-based activities for elementary students. Studies in China indicate that elementary school students' motivation toward language learning will increase after experiencing these dramabased teaching activities [10, 11]. Specifically, [9] indicate that role-playing activities can influence primary students' ability to learn a second language. DICE (Drama improves Lisbon Key Competences in Education) [12] suggests that children would concentrate more on their speaking when participating in role-playing activities. [13] described that students were given an opportunity to select their role in an imagined context through story-based drama activities, allowing children to feel more comfortable expressing their ideas and communicating with others in the target language.

However, there are challenges of drama-based pedagogy in practice in a china context. Firstly, more student-centred social interactions are required, as traditional Chinese language arts classes are primarily teacher-centred. Teachers are expected to cover every aspect of the texts and guide students to close textual analysis [14]

Secondly, The shortage of professional guidance limits the development of Educational Drama in the classroom. Educational Drama teaching training courses by training institutions are only available in certain cities, such as Beijing, Shanghai, and Nanjing [14].

\section{MUSIC-BASED PEDAGOGY IN EARLY CHILDHOOD LANGUAGE LEARNING}

Similar to the goal of music-based pedagogy in early childhood language development, drama-based activities were employed by studies to enhance students' communication skills [15, 16], phonetic skills [17], as well as speech and reading ability [18]. Studies also explained the importance of music in facilitating language learning motivation, investigated how musicbased activities were designed to motivate language learning [19-21]. However, limited literature investigates how music-based activities enhance young children's motivation to learn a language.

\subsection{Music-based activities in parenting skills and early childhood communication skills}

In England, both music specialists and speech and language therapists have already noticed the music's role in early childhood language achievement and developed a music-joint language learning pedagogy. 
[15] and [16] created a new musical pedagogy for early childhood language learning and communication called "Music for change" and "Salt music". In those programs, led by an early childhood music specialist and a speech and language therapist. Music for change aimed at supporting school readiness, speech and language. They recruited 1320 children aged between 0 and 4 years old and conducted a 10 -week-workshop. The project "Salt music" developed new music communication pedagogy based on "music for change" findings, worked with children 24-36months with communication difficulties and their families to enhance parenting skills and early childhood communication skills. Participated parents valued music activities such as sound practice, free play, and games with instruments as an effective tool to increase speaking confidence. Participated practitioners gained a transdisciplinary knowledge and integration between early childhood music practice and language and therapeutic interventions.

\subsection{Music-based activities in early childhood phonemic skills}

The multi-sensory music pedagogy were adopted in the US. [17] uses nursery rhymes games such as rhyme oddity tasks, completion games to enhance pre-school childrens' phonemic skills. This study recruited 20 three-year-old children and their teachers from a preschool in the Northeastern United States. Multi-model teaching strategies were employed for those participants, including "tactile and kinaesthetic", "visual and tactile", "role play and drama". Meanwhile, a variety of materials were supplied, including felt board, prop box and rebus poster. This study suggests that nursery rhymes facilitate early childhood phonemic skills; children could develop an awareness of sound patterns and make up spoken words through engaging with nursery rhymes.

\subsection{Music-based activities in language understanding and reading}

The classical early childhood music teaching methods were also mainly employed in France to reinforce primary school children's language ability. [18] conducted a two-school-year longitudinal study with $37-$ second grade primary schools' children recruited randomly in Southern France and who have no music training experience participated in music or painting training. A music 45 -minutes workshop led by a music specialist took place twice a week from October to May during the first school year and once a week during the second school year. The teaching pedagogy combines the classical music teaching methods of Kodaly and Orff, facilitates rhythm, harmony, timbre and harmony activities. The results show that music pedagogy may increase the students' understanding of speech and learning foreign languages. In addition, the study suggests that music pedagogy may increase children with dyslexia' reading ability.

\subsection{Music-based activities in early childhood language knowledge understanding and articulation}

The European teaching activities regarding music joint language pedagogy were promoted through the European Music Portfolio project: A Creative Way into Languages (EMP-L). [22] presents rhythmic pedagogy examples in modern language learning. The rhythmic methods were developed from a project named EMP-L to empower practitioners' modern language teaching. [22] described that rhythmic activities were employed to support pronunciation and articulation, vocabulary, and language knowledge; activities of music listening, dancing and singing were implemented to enlarge vocabulary and reinforce students' reading capacity; composing activities were aimed to facilitate creative writing skills. The role of music is valued as a powerful tool in 1) facilitating social integration, 2) overcoming language barriers, 3) empowering language knowledge understanding, and 4) enhancing communication skills.

\section{MUSIC-BASED PEDAGOGY IN A CHINESE CONTEXT}

The role of music in second language learning for adults has been investigated in a Chinese context. [23] Examined the effectiveness of using the song lyrics and genres in the ESL classroom with adult Chinese students on their vocabulary acquisition, language usage, and motivations. Three groups were compared by using the pretest and post-test. Each group received either complete song-based ESL instruction, song and nonsong based ESL instruction, or non-song based ESL instruction. The experiment consisted of six 90-minute classes. Pop songs from both American and British, such as tunes by the Beatles, Led Zeppelin, Van Morrison, Cat Stevens, the Rolling Stones, Nick Drake, the Who, and Pink Floyd, were employed. Activities of 1) listening and comprehension, 2) summarizing or writing, 3) vocabulary isolating and 4) word order was employed. The aims of using those songs are to develop pronunciation, listen and reading comprehension, grammar and stress patterns. The result shows that participants exposed to the most music obtained higher achievement and attitude on their score. It seems that there is a link between music ability language achievement in Chinese learning. Delogu et al. (2006) approved that adult student with a high melodic ability better detect tonal variations.

There is limited literature regards music activities in children's language learning. [24] emphasized the role of informal music activity participation on primary students' Chinese language academic achievements. In 
the study, There is a large sample which could present Chinese primary students from six provinces among the east, west, and the centre with high, average and low levels of economic development. 10958 fourth grades students from 627 schools aged from 9 to 11 were recruited from the study, including $47.8 \%$ boys and 52.2 girls. The result shows that informal music activities such as singing, dancing, playing of instruments, music listening positively informed participants' Chinese language academic achievement. Although the author compared formal and informal music activities and emphasized that informal music activities are more efficient in supporting students' Chinese learning than formal activities, there is no mention of a designed music pedagogy on students' language learning. More investigation on the validity of designed music activities on children's language achievement is needed.

\section{CONCLUSION}

The current literature shows that drama and music based pedagogy support early childhood language learning and development. Drama-based activities in early childhood language learning were developed systematically with corresponding teaching methods such as "role-playing" $[2,3]$, "script-writing" $[7,8]$ and "text interpretation"[5]. Music-based activities in early childhood language learning were analysed through teaching model among music teaching and language therapy $[15,16]$, sensory simulations, materials [17] and pedagogy [17, 18, 22]. In addition, studies have already investigated drama-based language teaching activities in pedagogy, curriculum and training programs; addressed the limitations and student-centred social interaction and the shortage of professional guidance in small cities [14].

However, studies regarding music-based activities still focus on adult language learning, limiting the scope of song lyrics and genres. Also, limited studies are investigating how music-based activities motivate early childhood language learning in a Chinese context. More studies need to look at music-based activities in early childhood language learning in both curriculum and teaching training in a Chinese context.

\section{REFERENCES}

[1] Coles, J., \& Bryer, T. (2018). Reading as enactment: transforming Beowulf through drama, film and computer game. English in Education, 52(1), 54-66.

[2] Stinson, M., \& Winston, J. (2011). Drama education and second language learning: a growing field of practice and research.

[3] Rosenblatt, L. 1978. The Reader, the Text, the Poem: The Transactional Theory of the Literary
Work. Carbondale: Southern Illinois University Press.

[4] Barrs, M. 1987. "Voice and Role in Reading and Writing." Language Arts 64 (2): 8-11.

[5] Stinson, M., \& Winston, J. (2011). Drama education and second language learning: a growing field of practice and research.

[6] Dundar, S. (2013). Nine drama activities for foreign language classrooms: Benefits and challenges. Procedia-Social and Behavioral Sciences, 70, 1424-1431.

[7] Michaud, M., \& Hooper, T. (2016). Cultivating student understanding of context through drama and scriptwriting. Scenario: A Journal of Performative Teaching, Learning, Research, 22-36.

[8] Bull, G., \& Kajder, S. (2005). Digital storytelling in the language arts classroom. Learning \& Leading with Technology, 32(4), 46-49.

[9] Ragnarsdóttir, Á. H., \& Björnsson, H. S. (Eds.). (2019). Drama in Education: Exploring Key Research Concepts and Effective Strategies. Routledge.

[10] Kang, Y. (2020). Using drama in primary school English teaching in China.

[11] Yuanyuan, C. (2019). Enhancing EFL Students' English Competency through Drama: A Case Study in a Primary School in China. English language teaching, 12(7), 68-74.

[12] DICE Consortium. (2010). The DICE has been cast: Research findings and recommendations on educational theatre and drama. Budapest: DICE Consortium.

www.dramanetwork.eu/file/Policy\%20Paper\%20lo ng.pdf.

[13] Chang, L. Y. S., \& Winston, J. (2012). Using stories and drama to teach English as a foreign language at primary level. Second language learning through drama, 15-30.

[14] Chi, X. B., Belliveau, G., \& Dong, B. F. (2021). Looking back and looking forward: educational drama in Chinese language arts education. Research in Drama Education: The Journal of Applied Theatre and Performance, 26(2), 312-317.

[15] Pitt, J. (2020). Communicating through musical play: combining speech and language therapy practices with those of early childhood music education-the SALTMusic approach. Music Education Research, 22(1), 68-86. 
[16] Pitt, J., \& Welch, G. F. (2021). Music in early education and care settings for communication and language support. The Oxford Handbook of Early Childhood Music Learning and Development.

[17] Harper, L. (2011). Nursery rhyme knowledge and phonological awareness in preschool children. The Journal of Language and Literacy Education, 7(1), 65-78.

[18] Chobert, J., François, C., Velay, J. L., \& Besson, M. (2014). Twelve months of active musical training in 8-to 10-year-old children enhances the preattentive processing of syllabic duration and voice onset time. Cerebral Cortex, 24(4), 956-967.

[19] Kao, T. A., \& Oxford, R. L. (2014). Learning language through music: A strategy for building inspiration and motivation. System, 43, 114-120.

[20] Kara, Z. E., \& Aksel, A. S. (2013). The effectiveness of music in grammar teaching on the motivation and success of the students at preparatory school at Uludağ University. ProcediaSocial and Behavioral Sciences, 106, 2739-2745.

[21] Jones, B. D. (2020). Engaging Second Language Learners Using the MUSIC Model of Motivation. Frontiers in Psychology, 11, 1204.

[22] Viladot, L., \& Casals, A. (2018). Ryming the Rythm and Measuring the Metre: Pooling Music \& Language in the Classroom. CLIL. Journal of Innovation and Research in Plurilingual and Pluricultural Education, 1(1), 37-43.

[23] Li, X., \& Brand, M. (2009). Effectiveness of music on vocabulary acquisition, language usage, and meaning for mainland Chinese ESL learners. Contributions to music education, 73-84.

[24] Guo, H., Yuan, W., Fung, C. V., Chen, F., \& Li, Y. (2021). The relationship between extracurricular music activity participation and music and Chinese language academic achievements of primary school students in China. Psychology of Music, 03057356211027642 . 